\title{
JULIÁN MEZA: \\ ENSEÑANZAS DE \\ LIBERTAD Y VERDAD
}

Juan Carlos Erreguerena*

\section{Conocí a Julián Meza en 1982. Yo} era un estudiante de economía del ITAM y Julián era mi profesor de alguna materia de Estudios Generales. En ese momento, yo intentaba ser de "izquierda" y Julián ya había iniciado lo que yo llamo la desmitificación de la izquierda, aunque en realidad muchos años después he descubierto que simplemente es la desmitificación a secas. Los mitos pueden ser buenos, siempre y cuando no te controlen y sepas que son eso, mitos.

Julián me desafió y yo acepté el desafío, a pensar, a salirme de los esquemas rígidos, inflexibles y hasta ciegos. No importa si estamos hablando del socialismo, políticamente correcto en aquel entonces y entre ciertas tribus urbanas; o, en el otro extremo, de la teoría económica neoclásica (como decía Enrique Dávila, si la realidad no se ajusta a la teoría, algún problema tiene la realidad).

En el fondo, creo yo, Julián invitó, y creo que muchos alumnos y amigos aceptaron la invitación, a explorar el camino del pensamiento, de la filosofía, de la ética y de la literatura. No digo que Julián fue el único, pero sí me atrevo a afirmar que eran (y son) una minoría los profesores (y los alumnos) que se atreven a abandonar las zonas mentales de confort y a explorar territorios nuevos. El riesgo es alto, pero el fracaso es seguro si uno se estanca en el pensamiento único.

*Economista por el ITAM. 
Con Julián la relación trascendió a amistad. Un grupo de alumnos nos reuníamos con él en su casa, en Las Águilas, y cenábamos también en algunos restaurantes, como uno italiano que también estaba en Las Águilas, el Trento. Algunas veces, a esas cenas también asistían el profesor Zorrilla y el profesor Astey. Eran reuniones en que uno aprendía muchísimo más que en el aula.

Con Julián hicimos algún viaje al Colegio de Michoacán, y ahí conocí al gran historiador Luis González. Por medio de Julián también conocí ni más ni menos que a Octavio Paz.

No recuerdo esa etapa de mi vida con nostalgia, porque en realidad sigo en ella. Es una etapa de pregunta, de aprendizaje, de creatividad, de cuestionamiento, de alegría.

Julián, gracias por tu inteligencia y por tu humor. 